DOI: 10.12731/2658-6649-2019-11-5-69-73

УДК 614.2

\title{
ДИНАМИКА ПОКАЗАТЕЛЕЙ, ХАРАКТЕРИЗУЮЩИХ ОРГАНИЗАЦИЮ ОБСЛЕДОВАНИЯ БЕРЕМЕННЫХ В ГОРОДАХ КРАСНОЯРСКОГО КРАЯ
}

Курбанисмаилов Р.Б., Наркевич А.Н.

В статье представлена динамика показателей, характеризующих организацию обследования беременных в городах Красноярского края за период с 2012 по 2016 гг. Отмечено, что в городах Красноярского края за период с 2012 по 2016 г2. произошло снижение доли женщин, не наблюдавиихся в женской консультации, а также увеличение охвата беременных женщин 3-х кратным скрининговым УЗИ обследованием и выявляемости врожденных пороков развития.

Ключевые слова: обследование беременных; беременность; перинатальный мониторинг.

\section{DYNAMICS OF INDICATORS THAT CHARACTERIZE THE ORGANIZATION OF EXAMINATION OF PREGNANT WOMEN IN CITIES OF KRASNOYARSK TERRITORY}

\author{
Kurbanismailov R.B., Narkevich A.N.
}

The article presents the dynamics of indicators characterizing the organization of examination of pregnant women in cities of Krasnoyarsk region for the period from 2012 to 2016, Noted that the cities of the Krasnoyarsk territory for the period from 2012 to 2016, there was a decrease in the proportion of women not seen in the antenatal clinic, and increased coverage of pregnant women with a 3-fold screening ultrasound screening and detection of congenital malformations.

Keywords: examination of pregnant women; pregnancy; perinatal monitoring. 
В Российской Федерации увеличивается количество женщин, встающих на учет по беременности до 12 недель беременности [1]. Своевременная постановка на учет беременной женщины позволяет вовремя скорректировать при необходимости ее состояние $[2,3]$. Известно, что отдельные состояния, возникающие в перинатальном периоде, являются ведущей причиной патологии и смерти в перинатальном и младенческом возрасте.

Целью работы явился анализ динамики показателей, характеризующих организацию обследования беременных в городах Красноярского края.

\section{Материалы и методы исследования}

Использованы данные Красноярского краевого медицинского информационно-аналитического центра за период 2012-2016 гг.

\section{Результаты исследования}

В целом в Красноярском крае за 5 лет доля женщин, не наблюдавшихся по поводу беременности, от всех принятых родов снизилась с 3,34\% до $2,28 \%$, в г. Шарыпово и Шарыповском районе - увеличилась с $2,49 \%$ до $3,01 \%$, в г. Назарово и Назаровском районе - снизилась с $1,53 \%$ до $0,0 \%$, в г. Минусинск и Минусинском районе - увеличилась с $0,19 \%$ до $0,98 \%$, в г. Енисейск и Енисейском районе - снизилась с 4,11\% до 3,45\%, в г. Боготол и Боготольском районе - снизилась с 7,74\% до 7,14\%, в г. Ачинск и Ачинском районе - снизилась с $2,27 \%$ до $1,18 \%$ и в г. Канск и Канском районе - увеличилась с 3,13\% до 4,26\%.

В отношении динамики доли женщин, которым проведено 3-х кратное скрининговое УЗИ обследование в городах Красноярского края в период с 2012-2016 гг. можно отметить следующую ситуацию: в г. Шарыпово и Шарыповском районе она снизилась с $82,03 \%$ до 72,64\%, в г. Назарово и Назаровском районе - снизилась с $76,59 \%$ до 74,82\%, в г. Минусинск и Минусинском районе - увеличилась с $81,57 \%$ до 89,20\%, в г. Енисейск и Енисейском районе - снизилась с $62,31 \%$ до $59,65 \%$, в г. Боготол и Боготольском районе - увеличилась с 51,90\% до 76,20\%, в г. Ачинск и Ачинском районе - увеличилась с $81,34 \%$ до $88,55 \%$ и в г. Канск и Канском районе - снизилась с 78,75\% до 77,92\%. В целом по красноярскому краю доля женщин, которым проведено 3-х кратное скриниговое УЗИ обследование, за 5 лет увеличилась с 77,15\% до 80,58\%.

Динамику доли женщин, у которых выявлены врожденные пороки развития (ВПР) ребенка от числа закончивших беременность в городах 
Красноярского края с 2012-2016 гг. можно охарактеризовать следующим образом. В целом в Красноярском крае доля женщин, у которых выявлены ВПР ребенка, увеличилась с 1,36\% до 1,67\%. В г. Шарыпово и Шарыповском районе она увеличилась с $0,71 \%$ до $1,25 \%$, в г. Назарово и Назаровском районе - увеличилась с 1,17\% до 1,57\%, в г. Минусинск и Минусинском районе - увеличилась с 1,65\% до 1,89\%, в г. Енисейск и Енисейском районе - снизилась с $2,35 \%$ до $1,18 \%$, в г. Боготол и Боготольском районе - увеличилась с $0,95 \%$ до $1,81 \%$, в г. Ачинск и Ачинском районе увеличилась с $0,96 \%$ до $1,48 \%$ и в г. Канск и Канском районе - увеличилась с $1,88 \%$ до $3,10 \%$.

\section{Обсуждение}

За период с 2012 по 2016 гг. в целом по Красноярскому краю снижается доля женщин, не наблюдавшихся по поводу беременности и повышается охват женщин 3-х кратным скриниговым УЗИ обследованием, что привело к увеличению выявляемости ВПР ребенка. Однако, данная тенденция отмечается не во всех городах региона. Так, увеличилась доля женщин, не наблюдавшихся по поводу беременности в г. Шарыпово и Шарыповском районе, г. Минусинск и Минусинском районе, г. Канск и Канском районе. При этом в г. Шарыпово и Шарыповском районе, г. Назарово и Назаровском районе, г. Енисейск и Енисейском районе, г. Канск и Канском районе снизился охват скрининговыми УЗИ обследованиями. Необходимо также отметить увеличение выявляемости ВПР на территориях всех анализируемых городских округов за исключением г. Енисейск и Енисейского района. Наиболее существенное увеличение доли женщин, у которых выявлены ВПР, за 5 лет произошло в г. Канск и Канском районе.

\section{Заключение}

Таким образом, в городах Красноярского края за период с 2012 по 2016 гг. произошло снижение доли женщин, не наблюдавшихся в женской консультации, а также увеличение выявляемости врожденных пороков развития и охвата 3-х кратным скрининговым УЗИ обследованием. Данную тенденцию можно оценить, как повышение качества организации обследования беременных на территории Красноярского края.

\section{Список литературы}

1. Шарапова О.В., Чумакова О.В., Филиппов О.С., Гусева Е.В., Садовникова В.Н., Ходунова А.А. Основные задачи модернизации службы охраны здо- 
ровья матери и ребенка // Здравоохранение: журнал для руководителя и главного бухгалтера. 2008. №8. С. 19-29.

2. Уйба В.В., Торубаров С.Ф. Оценка совершенствования мер системы организации акушерской помощи, направленной на снижение перинатальных потерь // Вестник новых медицинских технологий. Электронное издание. 2014. №1. C. 24.

3. Lasswell S.M., Barfield W.D., Rochat R.W., Blackmon L. Perinatal Regionalization for Very Low-Birth-Weight and Very Preterm Infants // JAMA. 2010. Vol. 304. № 9. P. 992.

\section{References}

1. Sharapova O.V., Chumakova O.V., Filippov O.S., Guseva E.V., Sadovnikova V.N., Khodunova A.A. Osnovnye zadachi modernizatsii sluzhby okhrany zdorov'ya materi i rebenka [The main objectives of the modernization of maternal and child health services]. Zdravookhranenie: zhurnal dlya rukovoditelya i glavnogo bukhgaltera. 2008. №8, pp. 19-29.

2. Uyba V.V., Torubarov S.F. Otsenka sovershenstvovaniya mer sistemy organizatsii akusherskoy pomoshchi, napravlennoy na snizhenie perinatal'nykh poter' [Evaluation of improvement of measures of the organization of obstetric care aimed at reducing perinatal losses]. Vestnik novykh meditsinskikh tekhnologiy. 2014. №1. P. 24.

3. Lasswell S.M., Barfield W.D., Rochat R.W., Blackmon L. Perinatal Regionalization for Very Low-Birth-Weight and Very Preterm Infants. JAMA. 2010. Vol. 304. № 9. P. 992.

\section{ДАННЫЕ ОБ АВТОРАХ}

Курбанисмаилов Ренат Бадрудинович, аспирант

Красноярский государственный медицинский университет имени профессора В.Ф. Войно-Ясенеикого

ул. Партизана Железняка, 1, г. Красноярск, 660022, Российская Федерачия

krasgmu05@mail.ru

\section{Наркевич Артем Николаевич, доцент}

Красноярский государственный медиџинский университет имени профессора В.Ф. Войно-Ясенеикого

ул. Партизана Железняка, 1, г. Красноярск, 660022, Российская Федерачия narkevichart@gmail.com 
DATA ABOUT THE AUTHORS

Kurbanismailov Renat Badrudinovich, postgraduate

Krasnoyarsk state medical university

1, Partizana Zheleznyaka, Krasnoyarsk, 660022, Russian Federation krasgmu05@mail.ru

Narkevich Artem Nikolaevich, associate professor

Krasnoyarsk state medical university

1, Partizana Zheleznyaka, Krasnoyarsk, 660022, Russian Federation narkevichart@gmail.com 